\title{
A Fuga para o Egipto: pulsação de cor e sentido num concerto (neo)barroco
}

\author{
Maria Theresa Abelha Alves \\ (Universidade Federal do Rio de Janeiro)
}

\section{RESUMO}

O presente artigo propõe uma análise intersemiótica da novela de Mário Cláudio, A fuga para o Egipto, a partir dos seguintes pressupostos: 1) A transformação em palavras do quadro homônimo de Giambattista Tiepolo, pelo exercício de ekphrasis, que reproduz o jogo de claro escuro, as proporções, o geometrismo, e toda a temática barroca que instruiu a pintura do artista veneziano. 2) A analogia que a novela estabelece com a música barroca, ao transformar a pintura em tema e ao conferir a cada personagem que monologa o estatuto de voz, configurando uma nova arte musical da "fuga". 3) A metamorfose da tela em texto como fruto de uma observação que, sensível e teoreticamente, acompanha a saga da humanidade e a evolução do artesanato à arte.

PALAVRAS-CHAVE: discurso intersemiótico, Barroco e Neobarroco, narrativa portuguesa contemporânea

\section{ABSTRACT}

The present article consists of an intersemiotic analysis of Mário Cláudio's novella A fuga para o Egipto. This analysis is based on the following assumptions: 1) The writer has transformed Giambattista Tiepolo's painting The flight into Egypt into words through the implementation of ekphrasis, which reproduces the chiaroscuro technique, the proportions, the geometry and the baroque themes which were used by the Venetian artist in his painting. 2) The novella establishes an analogy between itself and baroque music through the transformation of the aforementioned painting into a theme and by enabling each of its characters, who speak in monologues, to have a voice. This has conferred the "flight" a new musical art. 3) The metamorphosis of the painting into a text appears as a result of an observation of the human saga and the evolution of craftsmanship into art in a sensible and theoretical manner.

KEYWORDS: intersemiotic discourse; Baroque and the Neo-baroque;

Contemporary Portuguese narrative 
"É sempre e tão-somente o estudo que fala na presença da obra de arte, e todo o problema se reduz a decidir que tipo de discurso deva ser feito.”

Giulio Carlo Argan

No terceiro século de nossa era, Filostrato comentava, nas proximidades de Nápoles, as pinturas concernentes a Héracles, Afrodite e Dionisos que adornavam a casa em que vivia. Das notas que tomara para as visitas que guiava resultou um livro onde importava menos descrever os afrescos da morada que os explicar aos visitantes. Embora o gênero literário em que Filostrato escreveu suas Imagines existisse desde a descrição do escudo de Aquiles na Ilíada, o livro de Filostrato tornou-se um paradigma do que se convencionou chamar ekphrasis. Com a publicação, no início do século XVI, de uma Antologia Grega, de que constam muitos poemas ecfrásticos, o gosto pela ekfrasis se refina, tornando-se moda no século seguinte, quando "as relações entre poesia e pintura intensificam-se e tomam diversas formas para atingir uma magnitude e um grau de complexidade radicalmente novos" (SOBRAL, 1994, p. 37). Na época barroca, muitos poetas comentaram, descreveram e explicaram em seus poemas obras pictóricas e esculturais, como um elogio ao artista que as havia produzido.

Mário Cláudio, em A fuga para o Egipto (CLÁUDIO, 1987), retoma a prática da ekphrasis, numa feliz atualização neobarroca da moda seiscentista. Como um observador que diante da obra de arte conjuga a percepção e o pensamento, faz sensualidade e intelecto interagirem ao buscar reproduzir pelo vigor das palavras a pulsação barroca do quadro homônimo de Giambattista Tiepolo, empreendendo uma instigante viagem da tela ao texto. A novela que "estuda" o quadro, fazendo-o “falar', aciona, conjuntamente, a visão (percepção) e o pensamento (conceito), ilustrando a verdadeira experiência estética, aquela que não se restringe a uma recepção passiva e que, ao contrário, envolve frutífera interação de obra, artista e apreciador, isto é, reúne "os elementos essenciais que os olhos retiveram e a 'miraviglia' que esta percepção provocou” (FUMAROLI, 1988, p. 165). Assim a percepção visual interpreta as cores para adivinhar o possível que se esconde sob o vigor que o amálgama das tintas expressa, pois "É psicologicamente falso supor que nada é visto além daquilo que estimula a retina" (ARNHEIM, 1989, p. 7). O invisível que se aloja sob o visível é recuperado pelo escritor ao transformar as figuras do quadro em personagens dotadas de secretos pensamentos e aspirações que, ao serem externados, evidenciam como a percepção visual pode transformar a impressão pictórica em metodologia do conhecimento.

$O$ ato de admirar o quadro (admirar não só no sentido de olhar com deleite, mas, antes, no sentido de olhar junto, olhar com) faz do observadorestudioso, no caso o escritor, um cúmplice do pintor. A comunicação artística que se encena informa, transforma, atualiza e inventa os meios para criar nova forma. A imagem por esse processo de transformação se oferece mais à leitura que à contemplação. Mário Cláudio perfaz o caminho de sua fruição estética, considerando que gnose é gozo, e que o percurso do saber ou da fascinação do olhar corresponde ao discurso do prazer. Do ver ao teorizar em palavras, o novelista constrói uma linguagem própria onde a pulsação da tinta se inventa nas cores de uma escrita plástica, e a matéria-língua é manipulada como Tiepolo manipulara a matéria-cor. Se a fúria criadora do pintor se inscrevera nas camadas de tinta dispostas sobre o linho, a imaginação inspirada do novelista, com fúria semelhante, ganha corpo sobre o papel tingido pelas letras. A escrita renova a 
consciência da língua, tomando-a como veículo estético que filtra a visão, ao inserir geometrismos, paralelismos e simetrias (padrões inegavelmente visuais) no pensamento expresso por palavras. Mário Cláudio não empreende a metamorfose da arte pictórica em arte poética, no sentido literal, pois as formas de arte são sempre autônomas e preservam sua essencial vitalidade, todavia reconhece que entre elas estabelecem-se possibilidades múltiplas de colaboração e fecundação. Desse modo, o pintar e o redigir - meios de expressão diferentes - resultam semelhantes no estilo: a tela empresta ao texto o seu matiz, este rouba os ornatos barrocos daquela, provando que nada é

Mais evidente que a existência de uma espécie de parentesco entre as artes. Pintores [e] poetas são levitas no mesmo templo. Se não servem às mesmas divindades, servem desde logo a divindades análogas. (SOURIAU, 1990, p. 66).

Da tela emergem as tendências barrocas para a desmedida, para o excesso decorativo, para os arabescos e volutas ao gosto do tempo em que o veneziano a produziu (é a desmedida que precede a concepção do Arcanjo Branco, o excesso da decoração faz com que o quadro abrigue corvos e cisnes que não condizem com a cena bíblica motivadora, e são arabescos que compõem o recanto da barcaconcha). Ao escritor compete desvendar o significado de tais tendências. $O$ gigantismo do Arcanjo Branco, que torna disforme e desproporcional tal figura, provém do fato de ele ser (já agora como personagem da novela) o medianeiro do Altíssimo. Ele é o timoneiro do Criador e, dentre todas as criaturas concebidas como títeres pelo divino poder, é o mais desprovido de vontade própria e o mais provido de obediência. Os cisnes enamorados (convém lembrar que tais aves constituem metáforas animais de Vênus) são a lustral presença da paz (na tela se colorem de branco) sobre o limbo aquático (pintado em tons de marinho e negro). Se na tela tais motivos decorativos exibem o contraste barroco do claro-escuro, na novela que os interpreta representam a conjunção impossível, mas desejada, entre José e Maria, o casal apaixonado que a vontade perversa do Onipotente separou. No quadro Maria e José são passageiros da barca-concha que se deixam levar para o destino que lhes foi preparado, não se olham, mas olham alhures. Em que estariam pensando? O enigma proposto pela pintura compete ao artista da palavra desvendar. Na novela, Maria ousa pensar, ludibriando sua própria inocência, na primeira vez que viu José e o desejou, e José, por sua vez, foge de sua forçada castidade, ao ansiar que fosse seu filho, o que por filho lhe recusam, quando externa a vontade de ser para o Menino o pai da profissão, porque a paternidade biológica the fora castrada pelo Senhor e, por isso, Maria, em seu virginal devaneio, reconhece no esposo um "joguete do Altíssimo [...] assaltado que foi pelo mandatário terrífico [...]" (CLÁUDIO, 1987, p. 55) e vê o casto José como um ser que progride para "a morte de seus quadris, sem que nem a sorte lhe caiba, como a Onan, de na terra derramar a semente" (CLÁUDIO, 1987, p. 55). Se na "garganta faleceu a conversa" (CLÁUDIO, 1987, p. 55) entre o homem e a mulher marcados pela eleição divina, pois Tiepolo os concebeu silentes, na pena do novelista é José quem se dá conta da homologia entre o par de cisnes e o casal formado por ele e Maria, ao observar: "É como se a ausência de fala, que entre nós ambos intercede, subitamente se convertesse no casal de cisnes alvíssimos, à flor das águas, por onde deslizamos" (CLÁUDIO, 1987, p. 15-16). Os corvos, pequenas manchas negras surpreendidas nas alturas, no cerúleo espaço dos bem- 
aventurados, servem para sugerir a grande ameaça que sobre os humanos paira: o sentimento de culpa que o Criador insuflou em suas criaturas a fim de puni-las pelo único ato livre de que elas são capazes, a rebeldia. Se o quadro dispõe numa concha a Sagrada Família, a interação dos monólogos de cada figura transformada em personagem elucida ser o concheado a proteção oferecida pelo pintor aos grandes desprotegidos de Deus, o sacro trio que padece o peso da eleição.

O luminismo setecentista divide o quadro em massas de luz e de sombra, e a novela que o lê separa em dois grupos opostos as figuras, transformando-as em personagens monologantes. Um grupo é apolineamente iluminado, o outro é tingido por sombras dionisíacas. O quadro, através da contração de uma tonalidade difusa, delimita zonas picturais por meio de um jogo de diagonais. Uma delas forma a "prancha [...] servindo de portaló" (CLÁUDIO, 1987, p. 39). Outra "talha a cena, do canto inferior esquerdo ao canto superior direito, prolongando o timão do Arcanjo barqueiro" (CLÁUDIO, 1987, p. 43). A obliquidade das linhas divide a tela em "dois triângulos rectângulos, definidos por volumes criteriosamente seleccionados" (CLÁUDIO, 1987, p. 43), e assim, a contraposição nítida de luz e trevas intensifica o conteúdo dramático da cena pintada. O efeito barroco de claro-escuro emerge num matiz cujo tom sombrio se manifesta no limbo aquático, no peso da mácula da revolta inscrito no Arcanjo Negro, no turvo conhecimento de José e no "Emblema da paciência" (CLÁUDIO, 1987, p. 27) impresso no Burro, em contraposição ao tom de opalina claridade que se centra no Menino, ilumina a face de Maria e "explosiva e cegante" (CLÁUDIO, 1987, p. 60) brilha no Arcanjo Branco. Os efeitos de luz e sombras do quadro, recursos barrocos picturais, despertam o gosto pelas antíteses e contrastes, barrocos ornamentos textuais. No texto, os dois compartimentos diametralmente opostos se dividem pelo "Monólogo do Pintor" que é o monólogo central da novela.

Velazquez em Las niñas, metaforizando o advento artístico como fruto da visão que o artista tem do mundo, colocou-se na obra mediante a ocularidade do espelho, pintando-se ao pintar, e, assim, ilustrou não só as "meninas" da Casa Real, mas, sobretudo, uma concepção metapoética da arte. De igual modo, ao conceber o "Monólogo do Pintor", colocando Tiepolo no centro da novela, Mário Cláudio ratifica que o artista vive em sua obra, pois é nela e através dela que manifesta sua "querença de tudo ver" (CLÁUDIO, 1987, p. 38), seu peculiar modo de significar, seu "jogo de espelhos e de reflexos" (CLÁUDIO, 1987, p. 37). O "Monólogo do Pintor" contribui para que se interprete a tela como o "resultado de um processo dialético contínuo entre o artista e o meio espácio-temporal [...] produto de civilização que guarda em si os valores de seu criador" (CAMPOS, 1990, p. 66). Afinal, a arte é sempre a fecunda representação do pensamento do artista através de seus meios peculiares de produção e é por isso que, nesse monólogo central, se espreitam os bastidores da criação, quando se surpreende o pintor na escolha dos materiais, no cuidado com a alquimia dos corantes, quando "os tons e os matizes se dissolvem, divergem e se associam, destalham ou recusam congregar-se, se fazem iridiscentes, à luz do dia, uniformes e compactos, quando a noite cai" (CLÁUDIO, 1987, p. 42), ou quando se reconhece que a grandeza de Tiepolo nasce da lucidez de seus pincéis de pelo de marta, estes que são "utensílios convenientes, dedicados à mecânica melindrosa da absorção dos pigmentos, sem que destes se quedem encharcados, nem a eles permaneçam impermeáveis" (CLÁUDIO, 1987, p. 38), que fazem as cores vibrarem na paleta do artista. Tiepolo é personagem que atualiza o desejo biográfico que tem pontuado obras de Mário Cláudio, em que um artista se elege como ponto de 
partida para discussões de ordem metapoética e histórica. Em seu monólogo, o pintor fornece dados sobre sua vida, desde a infância, quando "de uma janela da Fondaco dei Turchi” (CLÁUDIO, 1987, p. 37) abriu os olhos ao espetáculo do mundo, até a maturidade, quando já encontrava dificuldade em pintar os "frescos palacianos" (CLÁUDIO, 1987, p. 45), em virtude de uma dor ciática, e, por outro lado, atualizando também o empenho do escritor em tecer um encomion à arte, fornece referências às suas obras e ao tempo em que foram executadas, talvez porque

Uma pintura que seja um ato é inseparável da biografia do artista. Constitui ela em si mesma um "momento" na mistura adulterada de sua vida - quer o "momento" signifique os precisos momentos empregados em manchar a tela, quer signifique a duração total do drama lúcido desenrolado em linguagem simbólica. $\mathrm{O}$ ato de pintar é da mesma substância metafísica que a existência do artista. (ROSENBERG, 1974, p. 14).

Tal como Velazquez, Tiepolo é, na concepção de Mário Cláudio, o pintor que se pinta (se biografa) ao pintar, e é de dentro da novela (ou do quadro) que funciona como divisor de tons. O encontro verdadeiro com a pintura do veneziano manifesta-se, no escritor português, como uma animação que, impondo seu impacto vital, flui da obra. O polarizado cromatismo barroco da tela, jogo do branco e do amarelo com os castanhos, passa a significar outras antíteses na novela neobarroca: conhecimento e aceitação do Absoluto versus seu desconhecimento e negação, proximidade do húmus original, leitura poética da telúrica coloração que configura o primeiro triângulo, versus o desejo de no “pináculo glorioso [...] afinal se alcandorar" (CLÁUDIO, 1987, p. 26), pois é em cromo claro, "esbatendo-se a exprimir a transparência" (CLÁUDIO, 1987, p. 42) que se compõe o celeste infinito. A tonalidade antitética da tela sugere, no texto, a dialética do mal e do bem que acompanha a travessia das figuras e que as transforma em metáfora da "hermética travessia em que embarcam os homens" (CLÁUDIO, 1987, p. 40).

O escritor sabe que a existência humana é sempre agônica, sabe que nela lutam duas forças opostas: a necessidade da luz, como consciência da Verdade, e o apelo da sombra, como a força da desrazão que atua no sono e no sonho da alma. O novelista sabe que a arte plenamente representa e interpreta os mais diversos aspectos da experiência humana. Então os três primeiros monólogos que ressaltam a condição material das criaturas, o visgo do barro genesíaco, a condição de "verme" (CLÁUDIO, 1987, p. 11) a que cada homem se encontra condenado, encenam o tema barroco da queda. As trevas que turvam os monologantes Arcanjo Negro, José e Burro dizem que cada qual se encontra preso ao terreal. Os traços psicológicos dessa prisão são a dúvida que torna interrogativo o devaneio de José, a ousadia do Arcanjo decaído que pretendera igualar-se à luminosidade divina e a servidão do Burro, apurada a cada geração. Em contrapartida, os três últimos monólogos que ao do Pintor se seguem, proferidos por Maria, pelo Arcanjo Branco e pelo Menino, dizem da solar e miraculosa perfeição dos escolhidos por Deus. Maria, ao aceitar integralmente a claridade, passa a ser a "escrava do Senhor" (CLÁUDIO, 1987, p. 51). A claridade absoluta ofusca e, ofuscada pela luz do Verbo, Maria não possui verbo próprio, por isso recita a cartilha de Ana, entoa as cantigas que esta lhe ensinara, e declama os salmos de Davi. Mergulhada no 
Espírito, permanece alheia ao que para ela fora reservado. Ofuscado pela luz do Criador, o Arcanjo Branco não possui ação própria, pois serve apenas de "arauto querido e execrado do Senhor" (CLÁUDIO, 1987, p. 57) que age através dele. A trajetória do mensageiro do divino é a anulação de si para a vivência de outra e soberana vontade, a do Supremo. O Menino, a mais iluminada das figuras, a que fora gerada na "substância do homem, débil fruto como ele, como ele jurado para a eternidade" (CLÁUDIO, 1987, p. 65), encontra o verdadeiro sentido de sua paixão na revelação do Burro que, embora mergulhado na (in)consciência das sombras, descobrira que o preço da luz é a anulação da individualidade, o que impossibilita a escolha. No quadro de Tiepolo, o Menino se apresenta dormindo, aconchegado ao seio materno. Na novela, o sono do Menino não é o sono da inocência, mas o da falta de esperança, antecipação da morte futura que as demais personagens, ominosamente, anunciam. Os dois triângulos de monologantes representam, pelo cromatismo do quadro e pela crucial dúvida dos personagens da novela entre o transgredir e o observar a lei, a atração bi-orientada que define os humanos.

Tiepolo oferece, em seu "quadrilátero, de quarenta e três por cinqüenta e sete centímetros" (CLÁUDIO, 1987, p. 39), o equivalente a um instantâneo onde se salienta a viagem-fuga e se anunciam os perigos a ela inerentes, quer surjam como os cúmulos que se acastelam sobre os fugitivos, quer apareçam com o "vôo [dos corvos] que pressagia a tempestade" (CLÁUDIO, 1987, p. 15), quer se figurem na "imensidão de linfas e de limos" (CLÁUDIO, 1987, p. 17), água escura sobre que a barca desliza e que encontra afinidade com os abismos do inconsciente humano, quer se espelhem nas vagas e nuvens que por trás da embarcação se formam como possíveis representações dos enigmas do ser. O pintor apresenta ao observador-estudioso imobilidade e dinamismo, através de uma ordem lógica, definidora do próprio fato pictórico. $\mathrm{Na}$ composição da cena, as superposições das figuras e a escala que lhes orienta o tamanho não são arbitrárias: o Menino está à frente de Maria e esta à frente de José, o Arcanjo Branco toma a dianteira do Arcanjo Negro sobre o qual se agiganta e se eleva, as figuras sobrepõem-se ao cenário, a Sagrada Família está à frente do Burro. A cena bíblica evocada pelo quadro desenrola sua "história" da esquerda para a direita, isto é, dos Arcanjos ao santo trio, direção em que o sentido da visão se desloca. É refletindo sobre tais imagens visuais que o escritor "lê" o quadro, organizando as personagens a partir dos planos fornecidos pelo pintor e comprovando que o mais elementar produto da cognição intuitiva repousa nos objetos definidos, na distinção entre figura e fundo. As figuras que estão em segundo plano são as que, face à luz, vivem na sombra, ao passo que as de primeiro plano são as iluminadas. A proximidade ou a distância de umas em relação a outras, a grandeza ou pequenez com que foram concebidas ilustram o sentido simbólico que habita cada imagem, sentido a que o artista da palavra tem acesso ao olhar de modo inquiridor para a obra, desvelando-lhe a configuração de forças dirigidas ou interpretando-lhe os vários componentes visuais geradores.

Ao fazer sua instigada visão passear pela pintura setecentista, o escritor contemporâneo lê a saga da humanidade, numa bíblia pictórica, desde o episódio da criação dos anjos ao da redenção de Cristo. O pintor veneziano concebeu tal saga como travessia, mediante o motivo da passagem, simbolizado pela barca. $\mathrm{O}$ escritor a recria através deste e de outros motivos, concebendo a fuga da Sagrada Família para o Egito não só através da Fuga para o Egipto, quadro de Tiepolo pertencente ao acervo do Museu Nacional de Arte Antiga de Lisboa, mas também 
através de outras fugas, num percurso da memória, paralelo ao do olhar endereçado à tela e por este ativado. Este percurso paralelo, viagem pelos demais quadros daquele que por sua "discreta estatura" fora cognominado de "Il Tiepoletto" (CLÁUDIO, 1987, p. 41), viagem pelas cenas do Antigo e do Novo Testamento, dilata o campo do visível até confundi-lo com a imaginação. Isso porque o impacto das imagens é acompanhado do segredo nelas contido: o seu prazer ou a sua dor, as cicatrizes deixadas pelo tempo ou as esperanças guardadas para o futuro, portanto as imagens pedem mais que a visão, pois representam a natureza múltipla que se esconde sob a aparência imediata. A visão contemplativa que o escritor apresenta diante do quadro é um exercício em que conjugados estão o em e o com para alcançar a essência da obra. É no quadro e com ele que o escritor vislumbra as interdependências e as ligações que pode estabelecer entre o que vê e o que lhe vem à lembrança, entre o que vê e seus conhecimentos, entre o que vê e as suas próprias referências culturais. É perseguindo este mais, que está no quadro, com ele e além dele, que o artista da palavra capta a organização dos elementos figurativos e a energia que o pintor lhes conferiu como abertura para a potencialidade de transfiguração, já no âmbito do observador. $\mathrm{Na}$ mente que olha o quadro, a memória expande a percepção e esta escoa para uma terceira margem, onde fragmentos da Bíblia ou dos evangelhos apócrifos são acionados, dando ensejo a uma escrita em que estes mesmos fragmentos, roubados ao lugar de sua origem, ganham na novela sentidos novos, ampliados, deslocados, invertidos, num trabalho neobarroco de "distorção e perversão" (CALABRESE, 1988, p. 185). O quadro, ponto de partida da novelesca fuga, revela-se um signo que, apesar da implícita demanda de uma decifração própria, pressupõe a leitura e pede o discurso. Ao escritor compete apostar na polivalência da imagem. É ele que joga com a capacidade de construir mundos que se representam num pormenor, transformando a composição, o arranjo, a cor e o traço de Tiepolo em elementos de linguagem que remetem para outras coisas. A natureza, com suas águas e nuvens, compõe um cenário ameaçador, a perspectiva com que o veneziano elaborou as figuras dos Arcanjos fazendo o Branco elevar-se sobre o Negro, as linhas formadas pelo remo e pelo portaló, a disposição dos protagonistas sagrados e dos figurantes animais, em suma, todos os componentes da tela delineiam um ambiente ficcional a explorar.

$\mathrm{Na}$ novela, as figuras transformadas em personagens narram, em seus singulares e contemplativos monólogos, as micro-histórias que lhes povoam a alma, fornecendo informações sobre o conteúdo representativo do quadro, desenvolvendo o que se sabe a respeito do episódio bíblico de que se originam e, simultaneamente, modificando o que se supunha saber sobre ele. Cada qual possui uma versão do acontecimento bíblico que protagonizam. A palavra capta a dimensão do gesto e comprova que a retórica amplia o movimento gerado pela magia da cor. Cada monologante perspectiva o universo pictórico do lugar onde se encontra a procurar uma explicação para si e para os companheiros de êxodo. Forma-se, então, um curto-circuito de olhares, pois cada personagem direciona olhos e lembranças para o acontecimento amplo que tematiza o quadro, confirmando as teorias óticas sobre a perspectiva: a posição que oferece uma experiência mental direta só é acessível ao eu perceptivo.

A apropriação neo-barroca efetuada por Mário Cláudio em A fuga para o Egipto não permanece reduzida apenas ao aproveitamento do claro escuro, das proporções, do geometrismo, dos ornamentos, da temática que envolve o bem e o mal, o sagrado e o profano, o céu e a terra, e a assunção da vontade de Deus ou a 
revolta e relutância em obedecer, temas consagrados da estética barroca. Além disso, numa analogia com a "arte da fuga", técnica musical da época barroca, o escritor explora a polifonia ao transformar a pintura em tema e ao tecer através do texto o contraponto ao quadro, conferindo a cada figura, cada personagem que monologa, o estatuto de voz. Cada personagem-voz, ao discorrer sobre a travessiafuga, foge, na verdade, para outra voz a fim de nela encontrar-se. Como numa fuga de Bach, o texto enseja um ricercare a sete vozes que entre si ou reproduzem, ou desenvolvem, ou invertem fragmentos de umas e de outras, fomentando variações. Como num concerto barroco, em cada voz estão escritos o sujeito ou tema e a resposta variante, numa exposição intencional de uma "arte da fuga". As diferentes versões, ou variações, da travessia em que todos se acham empenhados nascem dos diversos pontos de vista. $O$ aproveitamento da "arte da fuga" funciona, neobarrocamente, para fomentar a descrença em uma verdade original e única, pois toda história é feita de histórias, toda história é versão. Se a narração se dá mediante os sete monólogos, a multiplicação dos narradores serve para esclarecer que ler uma pintura é arte de perspectiva. Cada personagem, ou voz, é actante de uma viagem literal - a fuga referenciada que se inspirou numa passagem do Novo Testamento - e, concomitantemente, é sujeito de uma viagem metafórica - a fuga que se processa através dos devaneios, a fuga acionada pela memória. A mensagem da imagem visual é então levada aos longes geográficos e temporais. Cada personagem ao monologar está na barca e em outra parte. Cada personagem se surpreende no presente da fuga e nos pretéritos e futuros tempos de suas lembranças e de seus presságios. Como na "arte da fuga", as fugas várias conservam as afinidades tonais com o sujeito-tema, e as personagens evoluem num cromatismo sonoro do escuro (grave) ao claro (agudo). O texto de Mário Cláudio é musicalmente "bem temperado", pois as personagens José, Arcanjo Negro e Burro são as notas tônicas cujas dominantes são, respectivamente, Maria, Arcanjo Branco e Menino, numa exploração fecunda dos intervalos de quinta. Organizando pelos monólogos as sete visões, o novelista cria também uma composição unificada onde os diferentes elementos se fundem num todo coeso e as várias relações se integram e se harmonizam, modulando proporcional, recíproca e inversamente as figuras-vozes. Gêmeos da onisciência e da onipresença, os sete monologantes comprovam que ver é contemplar alhures. A ação da novela é resultado dessa dinâmica visual e da tensão inerente a cada monólogo.

Se a percepção do artista da palavra ao visualizar a obra do artista da cor busca decifrar sua estrutura, o monólogo por que dá voz a cada figura-personagem constitui o desmembramento da imagem unificada em suas partes, fruto da análise da referida estrutura. Compreender a fala de cada personagem é o modo por que o leitor, já agora o de Mário Cláudio, pode reconstruir a imagem percebida pelo escritor e simular, em seu próprio gozo estético, o gozo que aquele experimentou ao ver o quadro e que simulou na escrita da novela. A "leitura" atenta do quadro exigiu do escritor a cuidadosa observação dos vetores dos múltiplos olhares, porque o sentido da obra só se revela na simultânea presença de todas as suas partes. O novelista, colocando em sua A fuga para o Egipto a perspectiva no centro da cena, no foco de sua visão, insinua que fruir a pintura consiste em focalizar o espaço em que algo se apresenta para os olhos que percebem tal presença e consiste, ainda, em tecer o apropriado discurso que representa o percebido. Sua proposta poética é tornar viva a obra do artista da cor, por isso, em seu trabalho de 
análise, oferece a revelação da arte em geral e transmite o choque da grandeza que transforma o gesto banal de construir no gesto artístico de criar.

Os pensadores antigos faziam uma distinção entre técnica e possessão pelas musas, último estágio da poiesis que levaria à sempre desejada loucura divina. Reconhecendo que aquele que se preparava para o fazer iniciava a cadeia que culminaria no ato artístico, o faber, na figura exemplar de Hefesto, era considerado um ser divino. A técnica pressupõe uma aprendizagem, mas a possessão é vivência, furor de alma que gera a arte no milagre divino da criação. $O$ artista precisa conhecer a técnica para imprimir no que faz seu órfico e dionisíaco furor. Como revelação da arte, a novela de Mário Cláudio perfaz, entre suas inúmeras travessiasfugas, o caminho evolutivo do artesanato à arte e desta ao milagre. Não é aleatória a colocação do "Monólogo de José" no início, o "Monólogo do Pintor" no centro, e o "Monólogo do Menino" no final do texto.

O Carpinteiro ilustra o artesanato. Consciente de que a técnica se pode transmitir, deseja passar para o Menino a ciência da construção dos utensílios: "uma charrua ou um caixão", uma arca para as bodas, "uma rola que gemesse ruque-ruque" (CLÁUDIO, 1987, p. 10). A novela insinua que do brinquedo da infância ao esquife, passando pelos símbolos de sobrevivência - a alfaia agrícola e o baú do casamento -, toda a história do homem pode ser contada pelos objetos criados pelos "artífices [...] que por aí cumprem seus dias" (CLÁUDIO, 1987, p. 10), virtuosos-virtuoses como o "tosco artesão da poeira" (CLÁUDIO, 1987, p. 11), José.

O Pintor desvela o salto que inaugura a singularidade artística, fruto da identificação imaginativa de um eu com o objeto que de sua mão nasce. Relação de um sentir em, marca intrínseca da "possessão das musas". Por isso o nascer do Pintor para a arte é fruto da ebulição que o crescimento de Veneza provocava dentro dele, uma vez que é nele que a cidade dos canais crescia. Ao transpor para a tela, no desenho das personagens, o fogo de seu furor imaginante, o artista pensa: "Reconheço-os, de sopetão, como se um gênio me assaltasse, a senha me confiando dessa frase pictórica" (CLÁUDIO, 1987, p. 46). O segredo da arte de Tiepolo consiste na refulgência de seu ego objetivado, tensão extrema da subjetividade. Como toda arte, não se baseia na reprodução (por isso sua magia não se ensina, uma vez que é latência antes de ser potência), mas, sim, na descoberta de uma realidade única. Se "o pintor volta todas as suas faculdades perceptivas para dentro, para o reino de suas fantasias subjetivas, seus sonhos, suas imagens pré-conscientes" (READ, 1981, p. 94), cada uma de suas criações é sempre nova e única e o artista se inventa outro a cada recomeço:

Quem haverá, pois, que dome substâncias tais, com elas se familiarizando, até nisso se consumir? Gasta um pintor seus anos, a resolver tais segredos, à paleta volta sempre, como se tudo desconhecesse. E, no mesmo almofariz, se esmagam essas patelas, que esboroam, jamais são iguais, porque outro é o mês, outro o recanto onde estamos, outra a mão de quem sente, Giambattista Tiepolo. (CLÁUDIO, 1987, p. 43).

Apesar de ser a emergência da "possessão das musas", a arte é fruto de um trabalho, de uma técnica, de um ostinato rigore. O pintor representado no texto, ao desfazer e refazer o desenho, ao traçar e alterar os limites da barca que pinta, torna-se paradigma do artista em geral, no empenho de dominar a matéria de sua 
arte. Do mesmo modo, terminado seu trabalho criativo, este adquire a função de alegoria de toda obra artística. Assim a barca, objeto comum pintado, representa a transformação da insignificância num significante de plurais e inesgotáveis significados.

Se a arte é a expressão do vulcão interior, o milagre é o próprio mistério desse fogo. O prodígio compreende a transfiguração do precário, a surpresa que consiste em presentear o mundo com as maravilhas arrancadas ao banal. É a potência do mistério que frequenta o devaneio do Menino, fazendo a natureza a Ele se render, "transformando-lhe os vagidos em ervas e em pétalas" e transfigurando o "fiozinho de saliva" em "um relevo de prata" (CLÁUDIO, 1987, p. 15). O segredo dessa transfiguração não se desvenda. $O$ mistério, em seu étimo - muen -, é a ação de fechar os olhos e a boca, pois presenciar o prodígio não é vêlo nem teorizar sobre ele, é apenas sentir-lhe os efeitos como vivência da "loucura divina". O mistério se encontra no final da novela a simbolizar o último estágio do ato de criar. O Menino é o mistério, o milagre. José, na sua imperfeição, reconhece que "perfeito só Ele" (CLÁUDIO, 1987, p. 10), porque o único capaz de prodígios. O Menino reinventa o mundo a cada passo e, hiperbolizando a capacidade lúdica, geradora de todo ato de criação, transforma-se no "Enlevo de Nazaré" (CLÁUDIO, 1987, p. 70), em virtude das coisas espantosas de que é capaz: sua sabedoria, sua excepcionalidade. O ludismo do Menino, porque prodigioso, não pode ser previsível, tem que ser desconcertante. A novela sublinha tal desconcerto por muitos meios, ora fazendo o Menino ser justo através da vingança, como, por exemplo, no episódio de Salomé, a parteira castigada por duvidar da virgindade de Maria, e no da cura milagrosa dos doentes do "doutor excelente" (CLÁUDIO, 1987, p. 69), ora fazendo-O alterar o já feito, destruindo-o e reconstruindo-o a seguir, como no caso da vasilha que Ele de "propósito espatifava" (CLÁUDIO, 1987, p. 70), ora dotando-O de extraordinária potência com relação ao mundo animal e vegetal, ora ilustrando sua absoluta capacidade de insuflar vida ao que no barro modelara com suas pequeninas e milagrosas mãos, verdadeiramente de Deus. Por tudo isso os atos do Menino são desconcertantes, veiculam o enigma e pedem, como todo milagre, encantamento e silêncio. Findo o "Monólogo do Menino" não há mais o que dizer. Absorvidos pela luz que da criança prodigiosa emana estão José e o Pintor, pois a utopia de ambos é o poder demiúrgico da criação.

O quadro focaliza um segmento momentâneo, porém a história das personagens embarcadas, quando contada, está cheia de quandos. A "Fuga" escrita contrapõe ação e êxtase numa seqüência temporal, recuperando o tempo anterior e posterior da travessia dos monologantes. O tempo cronológico se define ou por alusão ao ofício religioso da "hora da noa" (CLÁUDIO, 1987, p. 90), ou pelo cantar do galo que anuncia a manhã, ou por referência a datas da biografia de Tiepolo. Recuperando o fluir temporal, o escritor transmuta a expressão estética da simultaneidade espacial do quadro, admitindo trajetórias manifestas por relações lineares na composição de cada personagem. Embora possam representar conexões e relações causais, as imagens imobilizadas pelo quadro estão presas nos limites da situação representada: o artista do pincel concebe a Sagrada Família embarcada para o Egito, sob a custódia dos Arcanjos. Com eles vão o Burro e os míseros pertences da pobre família. Como boa pintura que é, encoraja o espectador a perguntar o porquê disso. A resposta, todavia, fica por conta do devaneio do observador, pois a linearidade da sequência não faz parte da essência da pintura. Do fruidor-escritor é a tarefa de ordenar discursivamente o quadro, de 
lhe desvendar os enigmas, de interpretar cada traço, cada detalhe da cor, como uma declaração do artista, seu padrão de informações explícitas ou implícitas. O fruidor-escritor guarda as chaves que dão acesso à rica complexidade da composição pictórica, traduzindo-lhe a "signatura rerum, a marca das coisas, pela qual a aparência exterior revela a natureza interior" (ARNHEIM, 1989, p. 124). Assim a barca pintada por Tiepolo, com o sentido dinâmico de objeto que se desloca, adquire conotação heraclitiana: o destino humano é uma errância, travessia temporal sem volta.

O universal da errância humana é trabalhado pela novela numa versão individual, próxima da psicológica, e numa outra, coletiva, que se avizinha da sociológica. O primeiro bloco de reminiscências da criança sagrada apresenta suas recordações primordiais, uterinas: "Preso dos cordões de minha mãe, desenvolviame[...]" (CLÁUDIO, 1987, p. 65). A travessia contada expõe a "cena manifesta" de outra, latente, isto é, a do primeiro e traumático êxodo a que se está sujeito: o nascimento, o corte do cordão umbilical. Desse primeiro trauma, o destino individual passa para outros, os motivados pelas circunstâncias adversas em que o homem se prende e de que só foge mediante o devaneio e a arte. A barca pintada propicia, na novela, a "fuga" a tais circunstâncias. Tantas são as "fugas" quantos são os viajores que devaneiam. Tantas são as “fugas' quantos são os artistas e fruidores que sobre o tema se voltam.

O referencial adverso ao indivíduo o é também à coletividade. Sociologicamente, a barca que leva a Sacra Família para longes paragens simboliza o êxodo da terra natal que se corporifica na sangria da emigração, marca inconfundível da penúria econômica ou do despotismo político, como se depreende do "Monólogo de José":

Preparei-me, pois, para abandonar a Judeia, onde exercia Herodes seu império de raiva e de luxúria, de pusilanimidade e de miséria [...] Não me contive que não derramasse duas lágrimas. Era a primeira pelo país de que nos exilávamos, confrangido nas garras da tirania crudelíssima. (CLÁUDIO, 1987, p. 13).

A Fuga para o Egipto focaliza a diáspora da terra natal que, ao longo da história da humanidade, tem definido o povo judeu, metonimizando-a na fuga da Sagrada Família. Ao mesmo tempo, faz dessa fuga a metáfora de outros êxodos, de outras diásporas (como a emigração do povo português), metáfora do sonho de uma terra da promissão a que nunca se chega, porque a natal, com todas as suas mazelas, está definitivamente e "sem remédio inscrita no coração" (CLÁUDIO, 1987, p. 32). Assim, alegorizando tempos, espaços e destinos, a novela encena as relações sociais tensas e imprevisíveis, através dos sete monólogos. Nas emblemáticas personagens se inscrevem as fraquezas, as vinganças, e as invejas a que até o Menino está sujeito. Ao desejar que lhe oferecessem para suas brincadeiras, "uma bola colorida como a do filho de Nemias", ou "uma peneira como a da avó Ana” (CLÁUDIO, 1987, p. 67), está o Menino desobedecendo a prescrição que proíbe o cobiçar as coisas alheias. Ao tornar rijo e descarnado o dedo curioso de Salomé, a criança, que veio ao mundo para aniquilar a face deletéria do sagrado que a lei de Talião legitimava, demonstra-se seguidora do preceito "olho por olho, dente por dente". Nas paradigmáticas personagens se inscrevem os conflitos que tornam agônicos e tensos os relacionamentos. A polaridade dos Arcanjos denota que Deus Pai, grande jogador, elabora sua lição de 
harmonia no embate dos contrários: "Entre o Arcanjo Negro, que sofre, e o Arcanjo Branco que se regozija, marca o Eterno, em seu ardente alfabeto, o inconfundível timbre de Sua paz" (CLÁUDIO, p. 34). Nas simbólicas personagens se inscrevem os ciúmes, as paixões e as frustrações a que todos os humanos são sujeitos. O escritor, ao focalizar as personagens hieráticas, dá-lhes um retrato mais humano e menos santo, mais verdadeiro em sua heresia.

Apesar de todos os embarcados estarem envolvidos numa tarefa comum, a da fuga, o destino de cada um deles é solitário, como o é o destino de cada homem. No quadro, os Arcanjos não se encaram nem olham as demais figuras. Maria e José olham os longes de suas pessoais incertezas. O semblante denso de José sugere que ele perscruta a distância a fim de obter resposta para a pergunta angustiante que a si mesmo faz: "Que sorte nos calhará [...]?” (CLÁUDIO, 1987, p. 17). Maria olha alhures confiante na cantiga que com Ana aprendera e que usa para embalar o filho. Sós, portanto, estão as figuras do quadro. Sós estão as personagens da novela. A eleição do monólogo decorre da consciência que se tem de que todas as falas são monólogos, porque cada falante é um único e solitário ser na travessia da vida que, como viajor da barca-mundo, sujeita-se à incompreensão, voz sem eco na babel cotidiana, pois o grito do homem é, na solitária travessia da vida, inaudível, sempre. Assim Maria reconhece em José o "companheiro da solidão" (CLÁUDIO, 1987, p. 55) e este sabe que em sua relação com a esposa "O silêncio pairou sempre” (CLÁUDIO, 1987, p. 15). Por isso, nos seus falares, cada personagem discursa sobre si e sobre os outros, porém nunca entre si e com os outros.

A multiplicidade de formas e de cores da pintura permanece refletida na obra de ficção. A empatia que mobilizou o escritor foi proporcional à abrangência de sua experiência estética, do mero exame dos fatos visuais pelos quais o quadro pôde ser descrito, à descoberta dos fatos associativos por que o quadro foi compreendido. O impulso criativo acionado pela percepção fez surgir a letra que prodigiosamente diz a pintura. A verdadeira arte é sempre um continuar da concepção e invenção que começou na mente do artista, porque o impulso criativo, a loucura divina que explica a existência da arte, não prescinde do gozo intelectual que do ver passa ao estudar. Ativando a percepção e o pensamento, a obra de arte retira o ser de um tempo e o instala em outro: um presente gerundivo que aponta para a eternidade. Estar diante da obra é presenciar o evento artístico na inalterabilidade de sua perfeição. O observador, convidado a compartilhar do infinito presente que no "estou vendo" se constrói, vivencia a condição primeira, original, do flagrante advento da arte, o seu contínuo propor-se como algo que acontece no aqui e no agora: "A obra de arte, enfim, se faz presente no presente absoluto da consciência que a percebe" (ARGAN, 1992, p. 27). A intensidade e a plenitude da percepção alargam-se no estudo de duas dimensões: a imaginação da memória e a imaginação do futuro. A confluência dos dois tempos é o que na novela cria o presente gerundivo da arte. A fuga para o Egipto se inicia com o verbo no presente: "Lembro-me" (CLÁUDIO, 1987, p. 9). Nesse presente está José, a personagem que inicia sua "fuga", está o escritor que inicia sua contemplação interrogante pelo quadro que o motiva, está o leitor de Mário Cláudio que inicia sua travessia pela mancha tipográfica. Presente da pintura, presente da fruição, presente $\mathrm{da}$ arte, um incessante continuar de uma fuga necessariamente interminável. A presente eternidade da demanda não implica na inexistência de uma verdade intrínseca, porque ela está na obra como sedução e enigma. O novelista o soube ao contemplar um Tiepolo, contribuindo com sua palavra 
instituinte para a emergência da vitalidade pictural, palavra que recria, desperta, agita e instiga outras "fugas". O leitor o sabe, finda a travessia em que ele, na vivência compartilhada do visível barroco e do legível neobarroco, esteve gratificantemente embarcado.

\section{REFERÊNCIAS BIBLIOGRÁFICAS}

ARGAN, Giulio Carlo. "A história da arte". In: História da arte como bistória da cidade. São Paulo, Martins Fontes, 1992, p. 13-72.

ARNHEIM, Rudolf. Intuição e intelecto na arte. São Paulo, Martins Fontes, 1989.

CALABRESE, Omar. A idade neobarroca. Lisboa: Edições 70, 1988.

CAMPOS, Jorge Lúcio de. Do simbólico ao virtual. São Paulo: Perspectiva, 1990.

CLÁUDIO, Mário. A fuga para o Egipto. Lisboa, Quetzal Editores, 1987.

FUMAROLI, Marc. "La Galeria de Marino et La Galerie Farnèse: épigrammes et oeuvres d'art profanes vers 1600". In: Actes Du Colloque organisé par l'École française de Rome. Roma, 1988, p. 163-182.

READ, Herbert. $A$ arte de agora, agora. São Paulo: Perspectiva, 1981.

ROSENBERG, Harold. A tradição do novo. São Paulo: Perspectiva, 1974.

SOBRAL, Luís de Moura. Pintura e poesia na época barroca. Lisboa: Editorial Estampa, 1994.

SOURIAU, Étienne. La correspondencia de las artes. México-Buenos Aires: Fondo de cultura econômica, 1965. 